\title{
Using CIPP Model to Evaluate Student Entrepreneurship Program (SEP)
}

\author{
Sri Lestari Aldila Krisnaresanti Laeli Budiarti \\ Faculty of Business and Economic, University of Jenderal Soedirman, Purwokerto, Indonesia 53122
}

\begin{abstract}
This research aims to evaluate the Student Entrepreneurship Program (SEP) at University of Jenderal Soedirman. Evaluation includes aspects such as context, input, process, and product of this program. The population of this research are all students of University of Jenderal Soedirman, SEP supervisor and UMKM practitioner in Banyumas regency. This research used qualitative method. Data is analyzed by interactive model analysis technique which include components such as data collection, data reduction, data display, data quality test, and conclusion. Based on the evaluation, we conclude that the discrepancies among the guidelines published by Kemenristekdikti, SEP guidelines in UNSOED, and SEP execution on the field is still exist.

Keywords: Student, Entrepreneurship, Evaluation, CIPP

JEL Classification: M21

DOI: $10.7176 / \mathrm{EJBM} / 11-15-07$

Publication date:May $31^{\text {st }} 2019$

\section{Research Background}

Samo and Huda (2019) found that there is a need to develop interaction between academia and industry that operate in the same region. The interest of young academician's and natural exchange of ideas with industry can help in developing closer interaction which may lead to understand industry requirement and direct activities and entrepreneurial ideas according to the need of local industry. Universities with the help of government can also facilitate young academician's entrepreneur to promote entrepreneurial intention among the students.

Entrepreneurship is the main driving force for innovations and national development of a country. Directorate General of High Education of Ministry of Education and Culture in Indonesia had launched Student Entrepreneurship Program (SEP) since 2009. But the data shows that SEP still has not been able to decease the unemployment level of college graduates in Indonesia. Jenderal Soedirman University (UNSOED) is one of college that has been executing Student Entrepreneurship Program since 2009. UNSOED facilitate the students who have interest in entrepreneurship with entrepreneurship education and training, internship program, business plan arrangement, capital support, and business guidance so that they can start their business.

Lestari et.al (2018) found that Student Entrepreneurship Program in UNSOED is dealing with some problems such as the student lack of discipline in complying with the rules laid down in SEP, Unclear indicator of valuation for grants so that students are not motivated to make a good business plan, and many other. A lots of funding is not absorbed because students member of SEP was not discipline in proposing funding for each phases, lack of communication among SEP manager, and so on. Previous research also shows that the internship phase of SEP student member in SMEs had not been executed in the last three years. This finding is not consistent with the established procedure of SEP. Based on these problems, then we need to evaluate on Student Entrepreneurship Program that has been held. Evaluation was performed on four aspects : context, input, process, and product.
\end{abstract}

\section{Theoretical Review}

\subsection{CIPP Evaluation Model}

CIPP model was developed by Stufflebeam et.al in 1967 at Ohio State University. CIPP is an abbreviation from context evaluation, input evaluation, process evaluation, product evaluation. These four evaluation are one whole series. But according to Stufflebeam himself, in its execution an evaluator may only perform one type or combination on two or more of the evaluation type. It means that an evaluator does not have to use all four types. CIPP model as evaluation model that view the evaluated program as a system. Therefore if evaluator team had decided to use the CIPP model to evaluate the task program, then the consequence of that decision is that they have to analyze the program based on its components (Arikunto, 2004).

These four types of Stufflebeam evaluation have different analyzation object. Context evaluation is an effort to describe and give details on environment, fulfilled needs, served population and sample, and project purposes. So, context evaluation is aimed to assess the condition that is currently performed by an institution. The main purpose of context evaluation is to discover the strength and weakness of the evaluated side so the evaluator can give improvement direction needed based on need assessment and give consideration whether the aim/purpose is in line with the identified need assessment.

The next evaluation is input evaluation. Input evaluation aim to "problem solving" that drive the execution of the relevant program. This evaluation has to be able to predict the possibilities that may be faced in the future 
and also be able to see what the institution have in materiil and personil side. The next evaluation is process evaluation. Process evaluation is an evaluation regarding the execution of a program. Program evaluation (Arikunto, 2004) is directed to how far the activities in the program is executed according to the plan that point to "what" activities was held in the program, "who" is the person in charge/person responsible for the program, "when" will the activities end.

Process evaluation is aimed to fix the condition, so the evaluator is tasked to determine how far the evaluation plan is performed in the field, what problems was found there, and what innovation need to be done. These information is presented as feedback to the manager and staff. Product or result evaluation is directed to things that shows change on raw input. Result evaluation in CIPP model give comprehensive report regarding the effect of the program. of CIPP model have uniqueness. This model is bound to the decision making that is associated with program planning and operation. The table 1 shows the association of CIPP model with decision making and accountability.

Tabel 1. Association of CIPP model on Decision Making and Accountability

\begin{tabular}{|c|c|c|c|c|}
\hline Evaluation type & Context & Input & Proses & Product \\
\hline Decision & Objective & Solution & Implementation & Stopped/Terminated \\
Making & & Strategy & & Continued \\
& & Design & & Modified \\
& & Procedure & & Re-program \\
\hline Accountability & Objective & Strategy & Actual process & Achievement and Re- \\
& record & Option/Choice record & record & decision record \\
& & Design & & \\
\hline
\end{tabular}

Source : Nulhakim, 2009

CIPP model have some strength and weaknesses such as:

a. Strength :

1. CIPP has holistic approach in its evaluation, aimed to give very detail and wide description on a project, start from its context until its implementation.

2. CIPP has potentials to move/act in formative and summative evaluation area so it has the same advantage in helping executing the improvement/fix/correction during the execution of the program or in giving the final information.

b. Weakness :

1. Giving too much importance on how the process should be executed rather than the reality in the field.

2. The impression is too top-down with managerial nature in its approach.

3. Tend to focus on rational management rather than admitting the empirical realit complexity.

\subsection{Student Entrepreneurship Program}

Directorate General of High Education of Ministry of Education and Culture have launched SEP since 2009. SEP is executed in all State College and some Private College based on the selection by Private College Coordinator (Kopertis) with different funding allocation. Student Entrepreneurship Program is aimed to give science-andtechnology-based entrepreneurship knowledge, skill and attitude or passion. To the student so that it can change the mindset of job seeker to be job creator and become an entrepreneur who are resilient and success in facing the global competition. This program also aimed to drive the institutionalization or entrepreneurship unit in college so it can support the entrepreneurship program development. As the end result, the decrease in unemployment number of college graduates is expected.

There are several purpose of SEP. First, to grow entrepreneurship motivation in students; second, to build entrepreneurship mental attitude, those are confidence, aware on their identity, have strong motivation to achieve their dreams, never give up, hardworking, creative, innovative, risk-taker, have leadership capabilities, have clear vision, responsive on critique and suggestions, have empathy and social skills; third, to increase the skill and competency of students especially in sense of business; fourth, to grow high-educated new entrepreneur; fifth, to create science-and-technology-based new business unit; sixth, to build business network among business practitioner, especially between newbie entrepreneur and established entrepreneur; and seventh, to drive the creation of entrepreneurship education or learning model in college.

\subsection{Entrepreneurship}

Zimmerer (2004) said that entrepreneurship is the implementation od creativity and innovation to solve the problem and an effort to take the advantage the chance that is faced every day. Entrepreneurship is a combination of creativity, innovation, and courage to take the risk that was performed by hardworking to create and maintain new business. To be an entrepreneur is to be someone who is able to combine production facor such as natural resources, labor, material, and oher tools to increase the value higher than before.

Some empirical studies shows that there is a positive impact from entrepreneurship training or education 
program in university on feasibility and attraction on new business initiation (Fayolle in Graevenitz et al, 2010; Tzachev and Kolvereid, 1999). Therefore, university has the chance to develop entrepreneurship from people who are more competent and capable so that they can create high value SMEs (Edwads and Muir, 2005). SEP as one form of strategy in entrepreneurship education program is aimed to develop the student's softskill so they have entrepreneur character in their behavior.

\section{Research Method \\ 3.1 Research Approach}

This research used qualitative approach

\subsection{Types and Nature of Research}

This research is a case study on Student Entrepreneural Program at Jenderal Soedirman University. This research evaluate Student Entrepreneural Program using CIPP eveluation model that evaluate the program from four aspects : context, input, process, and product of SEP.

\subsection{Informan and Research Setting}

Informant in this research are student at the Jenderal Soedirman University, manager of SEP, and practitioner of SMEs. This research was performed at Jenderal Soedirman University in particular and Banyumas regency in general. The object of this research is SEP.

\subsection{Technique Data Collection}

Data required in this study include primary and secondary data. Primary data was collected by using in-depth interview technique, Focus Group Discussion (FGD), observation and survey on SEP stakeholders. Secondary data collection techniques including documentation and review of literature related to entrepreneurship and SEP in Jenderal Soedirman University. Secondary data that was collected are : 1) Data on Student Entrepreneurship Program's guidance book; 2) Data on SEP history at Jenderal Soedirman University; 3) Organizational structure of SEP manager; 4) Data on vision, mission, aim, strategy, and activities held on SEP at UNSOED; 5) Data on SEP participant/member at UNSOED; and 6) Oher data associated with this research, for example : SEP annual report at UNSOED.

\subsection{Technique and Data Processing Phase}

Data of this research was processed using data reduction methods, data display, and data categories. Data was divided into four categories such as program context, program input, program process, and program product.

\subsection{Data Quality Test}

Data quality test was performed by using source triangulation and data triangulation.

\section{Results and Discussion 4.1 Context Evaluation}

Context evaluation is an effort to describe te environment, fulfilled needs, served population and sample, and the aim of the project. Context evaluation inolving problems associated with the program's environment, both external and internal environment.

Context evaluation in this research is by identifying the needs for external and internal environment at Jenderal Soedirman University on Student Entrepreneurship Program. External needs analysis on Student Entrepreneurship Program can be analysed from probabilities and needs of society on high educational entrepreneur. Other than analysis on society's needs and probabilities on high educational entrepreneur, context evaluation also analyse the internal environment of the program, that is identifying the properness of Jenderal Soedirman University as the organizer of Student Entrepreneurship Program.

Results on context evaluation from external side showed that chance and need of society on high educational entrepreneur is very big. This can be seen from the number of unemployment in Indonesia, which means Indonesia still really need people who are able to create new job field so that the number of unemployment in Indonesia can be decreased. Data of the level of open unemployment in Indonesia from Central Bureau of Statistic shows that the level of open unemployment in Indonesia from February 2014-February 2015 has increased 300 thousand people from the previous year with 819.714 people are college graduates (increased 226.158 people from the previous year). This number are the parameter on the importance of entrepreneurship education in college so that the graduates not only become job seeker but also a job creator.

Jenderal Soedirman University is one of the state university that has been executing Student Entrepreneurship Program since 2009. Jenderal Soedirman University is deserve to implement this program because they have capable lecturers who are able to give entrepreneurship education to the student. UNSOED also has facilities to 
support the execution of SEP. Besides, UNSOED also have vast network woth the SMEs in Banyumas regency.

\subsection{Input Evaluation}

Input evaluation in this research assess the initial ability of the managerial of Student Entrepreneurship Program and students. Management of SEP is being held responsible by Vice Rector of Student Affair Division of UNSOED. Therefore the place or facilities used are the facilities that owned by Student Affair Division of UNSOED. SEP implementation has been held in organized. The manager held the program socialization in UNSOED environment. Program Socialization held are :

a) Through the headmaster of university and faculties.

b) Banner that is installed on strategical places in UNSOED campus

c) Posters installed on many sites inside the faculties in UNSOED campus

d) Leaflet spread on many Unit in UNSOED

e) UNSOED website and Business Incubator Center UNSOED

Student as input of SEP have to passed the selection phases to be able to receive capital from SEP. Selection phases of SEP participants including :

a. Assessment on administration/document requirements of applicants

b. Assessment on capacity, attitude and personality of SEP applicant through interview (IPK, managerial experience, organization experience, entrepreneurship experience and behavior)

c. Assessment on business plan through presentation of business plan in front of selection team. Aspects assessed are creativity and inovation, local content, multiplier effect, continuous financial feasibility, and business management.

d. Visitation to business site, to assess the feasibility of business location (if needed)

After passing the selection phases, the next phase is debriefing/training phase. Students who has passed the initial selection is obligated to attend this debriefing/training. Students who can follow the next phase are those who are fully participating in this training.

As for the requirements for SEP applicants are :

1. Students allowed to enroll the selection are students from three batches before the implementation (for undergraduate program) and two batches before the implementation (for diploma program).

2. Member of each SEP group should be across batches and across study program.

3. Students who are already received SEP from the previous year may submit for SEP one year after the initial program, by using the capital for the ongoing business development.

4. For students who did not fulfill the responsibilities (EXPO, MONEV) and still have debts/arrearages in the form of SEP report from the previous year may not enroll SEP in the next year.

5. SEP applicant hav to fill the registration form provided by PMW managerial team.

6. Proposal is attached by : Business plan and documents proof (partnership letterm PMW guide recommendation letter), certificate/charter and other explanation that support the competency of SEP applicant

7. SEP applicant only have one chance to propose the proposal of SEP.

8. All document of proposal SEP are colleced in one envelope, with identity of the participant.

Identification of SEP program shows that in 2015 the total amount of SEP proposal is 203 proposal with the total amount of applicants are 600 students. From that many proposal, those who passed the first selection phase are 111 proposal and the amount of funded proposal is 111 proposal with the total student until 287 students. In 2016 the total amount of SEP proposal is 212 proposal with the total students involved are 864 students. More than a hundreds proposal and 94 groups passed the first selection phase. While in 2017 the total amount of student group who apply for SEP are 230 groups and 140 groups passed the first selection phase and 130 students group received funding. Total capital that was distributed in 2015 is Rp 443.961.500,-, in $2016 \mathrm{Rp} \mathrm{309.700.000,'} \mathrm{and} \mathrm{in}$ 2017 Rp 39.135.000,-

Based on these finding, the socialization phase was less effective and less efficient. This can be learned when there was socialization event from university, not all of the student who attend the socialization are really interested in enrolling in SEP. Faculty only appointed students without considering the interest of student to entrepreneuring. Study program managerial also less involved in socialization process. Finding from students showed that the discipline of students is still low, one group still consist of students from the same batvh, business plan training still lack in depth because it only present the arrangement systematic, success story telling from successful entrepreneur that has given the good result only performed in university level, while some training participant from the faculty was only randomly appointed by the faculty without considering their interest in entrepreneurship so that this activities had missed the target population, training duration was very limited from morning till noon, on every faculty there is only one guide of activities, no terms of percentage of fund distribution so there was no agreement between the guide as judge, there has never been any brainstorming for guides to unify the vision, mission, and understanding on SEP including in proposal assessment. 


\subsection{Process Evaluation}

Process evaluation pointed at what activities was held in the program, who the person in charge of the program is, and when the program was held. The execution of SEP activities was initiated by socialization to all UNSOED student, then followed by selection of applicants, training of applicant, internship, funding allocation, start up business, guidance, monev, and expo. As for the activities after the applicant is declared passed and receiving funding are :

1) Funding Allocation

a) Capital will be given after MoU between the participant and manager is agreed by both sides.

b) Capital only allovated for business activities according to the approved business plan.

2) Business execution

a) Applicant who has passed the SEP selection will be announced to the Dean and parents of PMW participant (in the form of copy of rector's decree)

b) Every participant or business group will be accompanied by the companion lecturer(mentor) in executing their business activities

c) Duration of guidance by mentor is until December

d) During the execution of business, there will be monitoring and evaluation by SEP team formed by Rector of UNSOED.

3) Money

a) Class monev

Class monev is interview between Guide and SEP participant regarding the development of their business, by showing the example of the product and relevant documents of their business. Class monev has the purpose to learn the development of group business in executing their business, learnthe problems faced and find the solution, if the group business does not run then guide is allowed to suggest the termination of business (decided in SEP manager meeting).

b) Field monev

Field monev is a following activities from class monev in the form of visitation to the business site to prove the business activities. Decision from field monev is whether or not the business is feasible to continue or not

Series of SEP execution every year are as follow : 1) socialization in January to March; 2) business plan arrangement training and proposal administration selection in April; 3) proposal presentation, final announcement of proposal and training of participant in May; 4) business execution from May to December; 5) monev, progress report and expo I in September; and 6) expo II and final report submission in December.

We find some problems that still exist in the processing phase. The problems are are :

1) Delayed capital funding disbursement

2) There are SEP participants who did not submit their report

3) There has not been any effort to record the continuity of business of the SEP participant

4) Internship activities was not performed and this detained the achievement of SEP's purpose in building the business network between business practitioner, especially between newbie entrepreneur and established entrepreneur.

5) There is inconsistency between SEP guidance book and the real execution of the program because the internship activities was not performed.

\subsection{Product Evaluation}

Product evaluation is aimed to shows change in raw input (student). Product evaluation gives information regarding the success of SEP student participant to be an entrepreneur. The change that happen on student can be clearly seen on business ownership on students who has not own it before. SEP also create new entrepreneur with high education background, that is student who had been educated, guided, and accompanied during the execution of their business, so when they finished their SEP program they are able to continue their business by themselves with entrepreneur education they got during SEP. But not all of the SEP participant followed SEP activities according to the terms and requirements. Based on these finding, there are some participants who did not report their business and did not participate in expo. SEP participant who did not submit their report was sanctioned by the termination of their second phase funding. These sanction is a form of punishment so that the other SEP participant is expected to not do the same mistake.

\section{Conclusion and Recommendation}

5.1 Conclusion

1) Student Entrepreneurship Program in context is a program that is needed by society to increase the amount of entrepreneur with high education background so that the number of unemployment can be decreased 
2) Student as input in SEP has gone through selection process so the student who passed the selection really have good quality proposal

3) The main problem in processing phase is the internship activities that was not performed so the aim of SEP could not be optimally achieved.

4) Result from SEP is that the student become young entrepreneur, but there are also some student who did not followed the procedure to submit the report, which means their business had failed.

\subsection{Suggestion}

As for our suggestion for SEP are :

1) The internship activities need to be resurfaced again in student, even in different way. So that the purpose and benefit that has been written in the guidance book on SEP can be achieved

2) Terms and requirements in SEP guidance book should be revised by determining clear success indicator.

3) Integrating SEP activities with study program

\section{Acknowledgement}

1. Kemenristekdikti (Ministry of Research, Technology and High Education ) who gave us the chance through the PTUPT service grant so that the team are able to held the research.

\section{References}

Arikunto, Suharsimi \& Cepi Safrudin. 2004. Evaluasi Program Pendidikan. Jakarta: PT Bumi Aksara

Edwards, L.J \& Muir, E.J. 2005. Promoting Entrepreneurship at the University of Glamorgan through Formal and Informal Learning. Journal of Small Business and Enterprise Development; 12, 4; ABI/ INFORM GLOBAL. pg 613

Lestari, Sri., Laeli Budiarti, and Aldila Kresnaresanti. 2018. Problem Identification on The Implementation of Student Entrepreneurial Program. European Journal of Business and Management. Vol. 10. No. 2, pp. 36-42

Nulhakim, Rusman. 2009. Evaluasi percepatan belajar pada SMA "X" Jakarta. Jurnal Pendidikan dan Kebudayaan Volume 15 Edisi Khusus I, 2009. Jakarta: Badan Penelitian dan Pengembangan Departemen Pendidikan Nasional

Samo, A.H, and Noor UI Huda. 2019. Triple Helix and academic entrepreneurial intention: understanding motivating factors for academic spin-off among young researchers. Journal of Global Entrepreneurship Research pp. 1-15

Tkachev, A., Kolvereid, L., 1999. Self-employment intentions among Russian students. Entrepreneurship \& Regional Development 11, 269-280.

Zimmerer, W. Thomas. 2004. Essentials Of Entrepreneurship And Small Business Management. Prentice Hall 